\title{
CrimRxiv
}

\section{Annual Survey of Jails in Indian Country, 2018}

United States Bureau of Justice Statistics

Published on: Apr 29, 2021

License: Creative Commons Attribution 4.0 International License (CC-BY 4.0). 
